\title{
SEMIOTICKÁ ANALÝZA AKO METÓDA SKÚMANIA ŽURNALISTICKÝCH TEXTOV
}

\section{The Semiotical Analysis as the Method of Journalistic Texts Research}

Keywords: semiotical analysis, journalism, text, study, semiotics, lingustics

Contact: Univerzita Komenského v Bratislave; maria.stankova@uniba.sk

\section{Úvod}

Existuje množstvo definícií textu, ktoré sa líšia najmä v závislosti od obdobia, lingvistického smeru či metodológie. Semiotický prístup k textu predstavuje možnost' vnímat' text ako znakový jav v najširšom slova zmysle, ako súbor znakov na jednej strane a jeden konkrétny (koherentný, kohézny, interpretovatel’ný) znak na strane druhej. Text ako znak neexistuje vo vzduchoprázdne, ale povedané „kristevovsky“ - vzniká a existuje v pavučine iných textov. Je zložený zo znakov, ktoré dekódujeme $\mathrm{v}$ rámci istých konvencií, $\mathrm{v}$ rámci svojich skúseností a vedomostí, v rámci kontextu i v rámci spomínanej pavučiny ostatných znakov. Sféra žurnalistických textov ${ }^{1} v$ tomto kontexte predstavuje jednu z najzaujímavejších druhov pavučín textov. Táto pavučina je rozsiahla, viacdimenzionálna, dynamická a fungujú v nej znaky rôznych kódov, ktoré sa dopĺňajú, potvrdzujú či vyvracajú. Texty v nej však v súčasnosti už netvoria len pavúky (novinári), ale i ne-pavúky (iným slovom laici, dežurnalisti) ${ }^{2}$. Naznačená variabilita v oblasti využívania kódov a znakov rôznej povahy a v súčasnosti i v oblasti autorov žurnalistických textov si vyžaduje variabilný prístup i zo strany vedca, ktorý $\mathrm{k}$ nim pristupuje ako k objektu svojho výskumu.

Nazerat' na žurnalistický text je možné z viacerých uhlov a platí, že kol'ko uhlov nájdeme, tol'ko existuje i spôsobov, ako ich interpretovat', analyzovat' či skúmat'. Výhoda semiotického prístupu spočíva i v tom, že vd’aka skúmaniu jednotlivých znakov

\footnotetext{
${ }^{1}$ Využívame neterminologické pomenovanie „žurnalistický text“ $\mathrm{v}$ zmysle súboru textov produkovaných v rámci žurnalistiky (tlačenej, rozhlasovej, televíznej i online).

2 Dežurnalizácia je podla mediálnej filozofky Anny Sámelovej „označenie všeobecne prítomnej deprofesionalizácie žurnalistických remesiel (textových, zvukových aj obrazových) v médiách na báze internetu. Ide o stav prakticky neobmedzenej dostupnosti zverejňovania vlastných amatérskych článkov, audionahrávok, fotografíi či videí“ (Sámelová 2018: 27).
} 
a kódov, je možné dostat' sa do híbky textu - ked’že vedec nie je obmedzený jedným kódom a jednou sústavou znakov. Semiotika umožňuje skúmat' okrem jazykových znakov i napríklad typografiu, neverbálnu komunikáciu, vizuálnu stránku textu (obrázky, fotografie, schémy farebnost', umiestnenie textu ...), spôsob rozprávania / podávania informácie, pri televíznej žurnalistike kameru, strih, záber, pri rozhlase i TV zvukovú stránku reči, rôzne zvučky, dialogický aspekt, dížku vstupov a pod. Semiotika zdôrazňuje vo všetkých druhoch žurnalistiky i význam kontextu, vzt’ah medzi autorom a adresátom, intertextualitu, spôsob, ako ne/funguje text $\mathrm{v}$ spoločnosti, zámer a ciel' autora a mnoho d’alších aspektov, ktoré mediálna komunikácia v sebe obsahuje.

Semiotický prístup k mediálnym produktom (medzi ktoré zarad'ujeme i žurnalistické texty) je podl'a Johna Fiskeho a Johna Hartleyho možnost' ako zdôraznit', že existuje niečo, čo treba analyzovat' a stojí to nad politikou, správaním, vlastníctvom, dokonca i nad umením. Podl’a nich je tým niečím semióza (Fiske, Hartley 2004: 18).

Každý znak vzniká v procese semiózy (proces získavania či strácania významu). Podl’a Charlesa Morrisa „zahrnuje tři nebo čtyři faktory: to, co působí jako znak; to, k čemu se znak vztahuje, ten účinek na nějakého interpreta, díky němuž je př́slušná věc pro tohto interpreta znakem. Tyto tři komponenty sémiose lze nazvat znakové vehikulum, designátum a interpretans; jako čtvrtý faktor může být začleněn interpret“ (Morris 1972: 12). Vnímanie textu z hladiska semiózy sa však postupne rozširovalo, a tak ju Fiske a Hartley opisujú ako fakt, akt a náčrt získavania zmyslu v rámci kontextuálnych tlakov (Fiske, Hartley 2004: 18). Všetky uvedené zložky semiózy i faktory, ktoré na ňu vplývajú, sa zvyknú zohl'adňovat' i v semiotickej analýze.

\section{Semiotická analýza}

Semiotická analýza inherentne nastol'uje množstvo otázok, na ktoré sa snaží nachádzat' odpovede. Hoci vychádzame najmä z teórie Daniela Chandlera, štruktúru analýzy - konkrétne jej rozdelenie na štyri oblasti (predstavenie textu a tri stupne označovania) vnímame v súlade s poznatkami Johna Fiskeho a Johna Hartleyho³.

Na tri stupne označovania upozornili práve Fiske a Hartley vo svojej monografii Reading Television z roku 1978. Prvý stupeň môžeme chápat' ako vzt’ah medzi označovaným a označujúcim v rámci znaku - na tejto úrovni je znak sebestačný, Fiske a Hartley uvádzajú príklad fotografie auta, ktorá znamená konkrétne auto (Fiske,

\footnotetext{
${ }^{3} \mathrm{~V}$ česko-slovenskom kontexte ho priblížila i Renata Sedláková vo svojej knihe Výzkum medií (Sedláková 2014: 329-386).
} 
Hartley 2004: 25). Druhý stupeň označovania znamená, že k pôvodnému významu sa pridáva viacero kultúrnych významov - konotácií. Fiske s Hartleym pokračujú v metafore auta a vysvetl'ujú, že „v našej spoločnosti auto (alebo znak auta) často znamená mužnost' a slobodu“ (Fiske, Hartley 2004: 25). V tret'om stupni označovania sa konotácie z druhého stupňa „spájajú do komplexného, kultúrneho obrazu sveta, kompaktného a organizovaného obrazu reality, ktorej čelíme. Práve tretí stupeň spôsobuje, že auto sa môže stat' súčast'ou vyobrazenia industriálnej, materialistickej a vykorenenej spoločnosti“ (Fiske, Hartley 2004: 25).

Štruktúru semiotickej analýzy možno budovat' práve na opísaných stupňoch označovania. Najprv však je dôležité analyzovaný text predstavit'.

Preto je prvým krokom semiotickej analýzy stručná charakteristika textu. $\mathrm{V}$ tejto časti opíšeme médium, $\mathrm{v}$ akom text vznikol a realizuje sa; žánrové charakteristiky a kontext. V zásade sú to informácie typu - aký text analyzujeme, kedy vyšiel, kde, v akom rozsahu, aký má formát, kto je autor. V závislosti od typu textu sa môžeme sústredit' konkrétne (ale napríklad i žánrové) vlastnosti napríklad televíznej reklamy, podcastu či karikatúry v mienkotvornom denníku. Daniel Chandler odporúča spomenút' i modalitu textu - spôsob, ako text podáva informácie, či ide o faktografický, alebo fiktívny spôsob narábania s informáciami, či je objektívny, alebo subjektívny, či využíva realistický kód a pod. (Chandler 2001: 2). Okrem stručnej charakteristiky textu sa sústredíme i na obsahový aspekt text - téma, klúčové body.

Druhý krok semiotickej analýzy predstavuje uvažovanie $\mathrm{v}$ rámci prvého stupňa označovania. Pohybujeme sa na úrovni denotácie - aké znaky, aké kódy sú použité a aký je ich základný význam. Môžeme priblížit' syntagmatickú stránku textu - opísat' syntagmatické štruktúry (argumentácia, narácia, deskripcia, explikácia), charakterizovat' vzt'ahy medzi jednotlivými znakmi, nakol'ko sú funkčné, jasné, zrozumitel'né. $\mathrm{V}$ tomto bode sa možno zamerat' i na paradigmatický aspekt textu - do akej paradigmy môžeme zaradit' analyzovaný text (z hl'adiska média, žánru, témy)? V závislosti od typu textu môžeme $\mathrm{v}$ tomto bode charakterizovat' i napríklad farbu, neverbálnu komunikáciu, strih, zábery, rozmer, umiestnenie vo väčšom celku. Tieto aspekty v druhom kroku semiotickej analýzy popisujeme - definujeme ich prvotný význam, z hl'adiska konotácí́ sa k nim môžeme vrátit' v tret’om kroku.

Ten sa opiera o druhý stupeň označovania, pohybujeme sa teda $\mathrm{v}$ rovine konotácíi. V tejto časti je dobré zamerat' sa na obrazné pomenovania (metafory a metonymie), ale i napríklad frazeológiu - ako fungujú v rámci textu, nakol'ko sú zrozumitel’né, ako ovplyvňujú preferované čítanie, nakol'ko súvisia s kontextom a pod. 
Rovnako je $\mathrm{v}$ nej priestor na načrtnutie intertextuálnych vztahov, $\mathrm{v}$ rámci ktorých je dobré načrtnút' i existenciu a fungovanie skúmaného textu v rámci žánru.

Posledný krok semiotickej analýzy sa opiera o tretí stupeň označovania, pri ktorom Sedláková využíva označenie ideológia (Sedláková 2011: 337). Opiera sa jednak o spomínanú definíciu Fiskeho a Hartleyho, no úzko súvisí i s mytológiou Rolanda Barthesa. Ten mýtus funguje ako metaznak, prehovor, ktorého intencia je dôležitejšia než jeho význam. Mýtus predstavuje „spôsob, ako konkrétna štruktúra predvádza abstraktné témy a ako hierarchia, hodnoty a nerovnosti v spoločnosti prezentuje ako prirodzené“ (Jirák, Köpplová 2015: 258). Podl’a Barthesa „mýtus má imperativní, interpelativní charakter: vyvstal z určitého dějinného konceptu, vynořil se př́mo z nahodilosti (hodina latiny, ohrožené impérium), ovšem vyhledává právě mne: je obrácen ke mně, podléhám jeho intencionální síle, vyzývá mne, abych príjal jeho rozpínavou nejednoznačnost" (Barthes 2004: 123). Jeho ciel'om je teda odhalit' ideológiu v pozadí skúmaného textu, spoločenské a kultúrne tlaky, ktoré de/formujú isté významy. Sústredíme sa na otázky, aký ciel' autor sledoval svojím textom, či sú nejaké znaky alebo významy v texte potlačené a iné naopak zvýraznené; či je text zrozumitel’ný len pre istý výsek adresátov (v závislosti od vzdelania, vierovyznania, rodu ...), alebo pre každého, či by sa interpretácie rôznych adresátov líšili v závislosti od rôznych situácií; či by zmena kontextu zmenila interpretáciu textu.

Teoreticky je možné pristúpit' $\mathrm{k}$ analýze tak, že všetky znaky, ktoré v prvom roku identifikujeme a opíšeme $\mathrm{v}$ druhom kroku na úrovni prvého stupňa označovania, môžeme v d'alších krokoch analyzovat' d’alej. V nadväznosti na príklad auta, ktorý využili Fiske a Hartley, by sme mohli uvažovat' o takejto forme semiotickej analýzy:

\begin{tabular}{|c|c|c|c|}
\hline predstavenie textu & 1. stupeň označovania & 2. stupeň označovania & 3. stupeň označovania \\
\hline fotografia auta & auto, motorový prostriedok & sloboda, nezávislost', & konzumná spoločnost' \\
& so 4 kolesami & finančná zabezpečnost' & \\
& & & \\
\hline
\end{tabular}

Obrázok 1: Náčrt krokov semiotickej analýzy

Stručne sme naznačili, čo môže byt' súčast'ou semiotickej analýzy. Teraz sa pokúsime uvedené informácie aplikovat' do praxe a na konkrétnom príklade naznačíme, ako funguje semiotická analýza pri skúmaní žurnalistických textov. 
Objektom analýzy bude titulná strana slovenského týždenníku .týždeň (Obr. 1). Tento časopis v slovenskom mediálnom systému funguje od roku 2004 a predstavuje typ média so zameraním na spoločenskú a politickú publicistiku.

\section{Semiotická analýza titulnej strany týždenníka .týždeň z 13. 2. 2016.}

1. Objektom semiotickej analýzy je titulná strana týždenníka, ktorá má formát A4 a je orámovaná červenou až bordovou linkou. Okrem rámu je v tejto istej farbe i bodka v názve týždenníka. Inak je obálka čiernobiela. Obálka obsahuje obrazový prvok (portrét vtedajšieho premiéra Roberta Fica) a slová (jazykové znaky): týždeñ; normalizácia; kčomu smerujeme s Ficom. Týždenník vychádza v pondelok.

2. Na obálke sú využité jazykové znaky, portrét a tri farby. Čierno-biely portrét zobrazuje bývalého premiéra vlády SR Roberta Fica, ktorý je graficky upravený Fico má okuliare, výrazne bledšie vlasy, než má v skutočnosti a viditel'nú plešinu. Portrét nereflektuje realitu, nie je jej verným odrazom, nejde o fotografiu, skôr o koláž

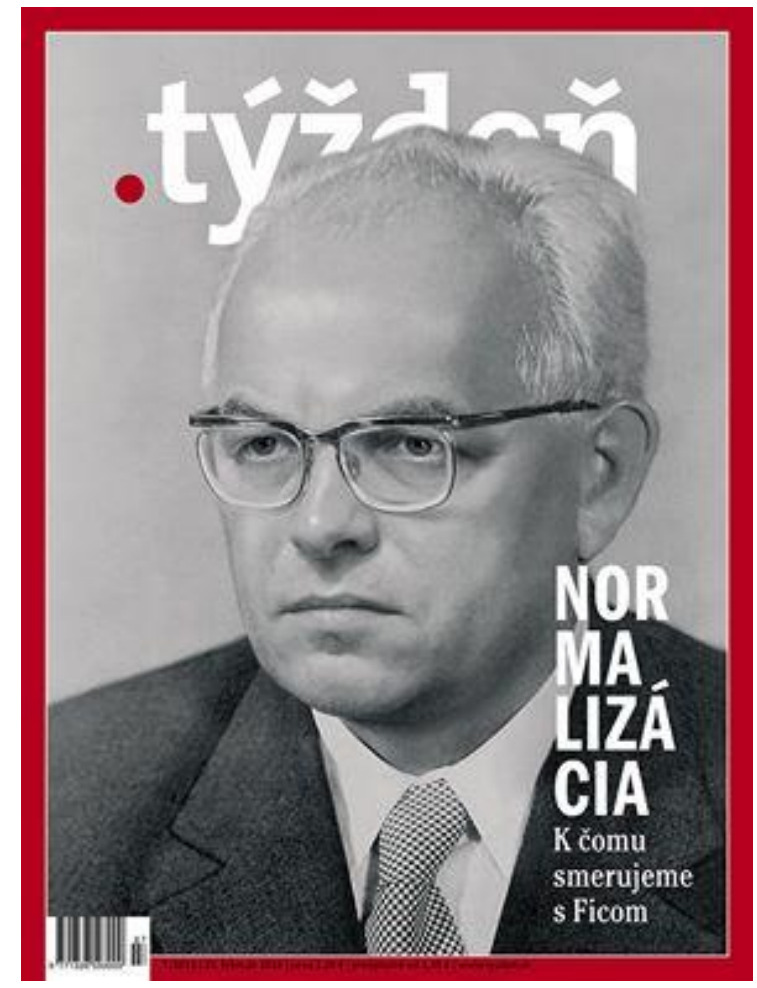

Obrázok 2: Titulná strana týždenníku .týždeň (13.2.2016) upravenú v grafickom programe. Portrét je dominantným znakom skúmaného textu. Okrem názvu týždenníka obsahuje titulná strana slovo „normalizácia“, ktoré je napísané kapitálkami, boldom, bezpätkovým písmom a je rozdelené na štyri časti (NOR - MA - LIZÁ - CIA), nie však podl'a slabík, ani podl'a morfém. Jazykový znak - slovo normalizácia podl'a kodifikačnej príručky Krátkeho slovnika slovenského jazyka znamená: 1. normalizovanie; 2. obnovenie tvrdej línie komunizmu po r. 1968 v býv. ČSSR; obdobie od tejto udalosti do r. $1989^{4}$.

Pod týmto slovom sa nachádza veta - K čomu smerujeme s Ficom, ktorá nie je ukončená interpunkčným znamienkom, čím ostáva nejasná modalita vetnej výpovede. Tento súbor znakov má iný font (pätkový, menší, menej výrazný) a vzbudzuje dojem

\footnotetext{
4 Krátky slovník slovenského jazyka. Dostupné z: https://slovnik.juls.savba.sk/?w=normaliz\%C3\%A1cia\&s $=$ exact $\& \mathrm{c}=\mathrm{V} 20 \mathrm{a} \& \mathrm{cs}=\& \mathrm{~d}=\mathrm{kssj} 4 \& \mathrm{~d}=\mathrm{psp} \& \mathrm{~d}=\mathrm{sssj} \& \mathrm{~d}=$ orter $\& \mathrm{~d}=\mathrm{scs} \& \mathrm{~d}=\mathrm{sss} \& \mathrm{~d}=$ peciar $\& \mathrm{~d}=\mathrm{hssj} \mathrm{V} \& \mathrm{~d}=$ bernolak $\& \mathrm{~d}=\mathrm{n}$ oundb\&d=orient\&d=locutio\&d=obce $\& d=$ priezviska\&d=un\&d=pskcs\&d=psken\# (2020-04-29).
} 
vety začiatočným vel'kým písmenom prvého slova. Všetky jazykové znaky okrem spomínanej bodky v názve časopisu sú vytlačené v bielej farbe.

Rozloženie jednotlivých znakov zo žurnalistického hl'adiska môžeme vnímat' ako bežné súčasti titulnej stránky periodika - názov média, grafický prvok, titul, podtitulok. Rozloženie, obrazový prvok ako dominanta a stručné textové prvky naznačujú, že titulná strana je súčastou paradigmy titulných strán týždenníka.

3. Farebná kombinácia titulnej strany sa dá interpretovat’ ako symbol zašlých čias - potvrdzuje to i štýl portrétu (kravata, okuliare). Na titulnej strane zároveň figuruje červená farba ako symbol komunizmu. Pri takejto interpretácii červenej farby treba byt' ostražitý, pretože i letmý pohl'ad na viaceré titulné strany časopisu .týždeň naznačí, že červené orámovanie titulnej strany a červená bodka v názve média sú najčastejším farebným vzorom. ${ }^{5}$

Portrét ex-premiéra Roberta Fica budí farebnost'ou, oblečením, okuliarmi i kravatou pocit, že ide o portrét prezidenta ČSSR, aké zvykli visiet' na úradoch a školách medzi rokmi 1948-1989. Portrét nielenže evokuje funkciu prezidenta, podobá sa (vlasmi, okuliarmi) na Gustáva Husáka, predstavitel’a normalizácie. S týmito konotáciami priamo súvisí slovo normalizácia, čo naznačuje preferované čítanie titulky. Rozdelenie slova na štyri časti môže evokovat' slabikovanie - typické i pre výrazné či výhražné prehovory. Ako sme naznačili vyššie, veta $K$ čomu smerujeme s Ficom nie je ukončená interpunkčným znamienkom, jej modalita teda zostáva neznáma - tento jav môže byt' spôsobený bud' redakčným úzom, alebo môže reprezentovat' zámer - adresát tak nie je schopný jednoznačne interpretovat' výpoved', ktorá by bola zrozumitel'nejšia, ak by bola ukončená bodkou, tromi bodkami, výkričníkom či otáznikom. Interpunkčné znamienko by poskytlo d’alší smer interpretácie. Pri uvedenej vete je však treba spomenút' minimálne dve d’alšie konotácie - nachádza sa v nej sloveso smerovat', ktoré je obsahuje koreňovú morfému smer. Smer-SD je názov politickej strany, ktorej lídrom je práve Robert Fico a ktorej politiku autor titulnej strany usúvzt’ažnil s normalizáciou. Slovo normalizácia môže byt' i odpoved’ na nevypovedanú otázku - kam smerujeme. Inú konotáciu predstavuje istý myšlienkový konštrukt, ktorý sa už niekol'ko storočí objavuje v slovenskej literatúre, či umení - protiklad my verzus oni (naše verzus cudzie). Veta Kam smerujeme s Ficom pracuje is touto konotáciou, čo naznačuje jej gramatická štruktúra (my a on (Fico)). Negatívne vnímanie normalizácie umocňuje i výraz tváre, ktorý možno vnímat’ ako znak v rámci kódu neverbálnej komunikácie.

4. Z hl'adiska tretieho stupňa označovania $\mathrm{v}$ tomto prípade treba spomenút' preferované čítanie v zmysle snahy autora primät' (vedome či nevedome, implicitne či

\footnotetext{
${ }^{5}$ Pre zaujímavost': v roku 2020 má z doterajších 19 tituliek červený vzor 12, v roku 2019 to bolo 35 z 50 tituliek.
} 
explicitne) adresáta čítat' text tak, ako to autor vyžaduje. Je zrejmé, že preferované čítanie tejto titulky je založené na negatívnom vnímaní osoby Roberta Fica, ktoré vychádza z konotácií portrétu i slova normalizácia.

Toto negatívne hodnotenie možno vnímat' ako ideologický aspekt - titulná strana (i celý časopis) zrejme nie je určený voličovi Smer-SD, či človeku, ktorý adoruje bývalý režim, povedzme konkrétne Gustáva Husáka. Je však možné, že takýto typ adresátov by mohol teoreticky titulnú stranu časopisu vnímat' i pozitívne, ak by nenastalo preferované čítanie.

\section{Záver}

V predloženej štúdii sme sa pokúsili načrtnút' jednotlivé kroky semiotickej analýzy $\mathrm{s}$ dôrazom na jej využitie $\mathrm{v}$ rámci skúmania žurnalistických trendov. Výhodou semiotického prístupu $\mathrm{k}$ týmto typom textov je bezpochýb jej široký záber (možno analyzovat' takmer akýkol'vek typ textov zo všetkých typov médií) a jej snaha dostat'sa pod povrch textu - odhalit', ako fungujú jednotlivé znaky, ktoré autor využíva. Najčastejšie sa využíva práve tam, kde sa stretávajú viaceré kódy (prirodzený jazyk a obrazová zložka), no nemusí to byt' pravidlom, a možno ju aplikovat' napríklad na výskum titulkov článkov.

\section{Summary}

In this study we tried to describe basis of semiotic analysis with regard to its usage in journalistic texts research. After short description of current approaches to journalistic text we introduced some basics information about semiosis and three orders of signification (based on Fiske - Hartley theory) which constitutes three of four steps of semiotic analysis structure. First step of semiotic analysis can be a short introduction - is a characteristics of the text), at second step we try to recognize all signs in the text and point at them meaning. Third step of semiotic analysis deals with connotation level - we are looking for metaphors, metonyms and trying to identify intertextual relationships. Last step can be called ideology because its aim is to point at culture, social and pragmatic aspects of the text which can also signify stereotypes and culture manipulation with reality.

Then we tried to prove these information on short semiotic analysis of concrete journalistic text - the title-page of Slovak magazine .týždeň, which depicts former prime minister Robert Fico. 
We can see that semiotic analysis offers way how to look beyond the text, because it is trying to describe the structure of signs used in researched text.

\section{Literatura}

Barthes, R. Mytologie. Praha: Dokořán, 2004.

Fiske, J., Hartley, J. Reading television. London and New York: Routledge, 2003.

Jirák, J., Köpplová, B. Masová média. Praha: Portál, 2015.

Morris, Ch. Základy teorie znaki̊. Praha: SPN, 1972.

Sámelová, A. Moc a pravda v podmienkach Rozhlasu a televízie Slovenska. Bratislava: Univerzita Komenského v Bratislave, 2018.

Sedláková, R. Výzkum médií. Praha: Grada, 2014.

\section{Elektronické zdroje}

Chandler, D. Semiotics for Beginners: D.I.Y. Semiotic Analysis. Dostupné z: https://comm156.pbworks.com/f/Semiotics+for+Beginners_+D.I.Y.+Semiotic+ Analysis.pdf. (2020-04-29).

Kačala, J. (ed.) Krátky slovník slovenského jazyka. Dostupné z: https://slovnik.juls.savba.sk/?w=normaliz\%C3\%A1cia\&s=exact\&c=V20a\&cs= $\& \mathrm{~d}=\mathrm{kssj} 4 \& \mathrm{~d}=\mathrm{psp} \& \mathrm{~d}=\mathrm{sssj} \& \mathrm{~d}=$ orter $\& \mathrm{~d}=\mathrm{scs} \& \mathrm{~d}=\mathrm{sss} \& \mathrm{~d}=$ peciar $\& \mathrm{~d}=\mathrm{hssj} \mathrm{V} \& \mathrm{~d}=\mathrm{ber}$ nolak $\& \mathrm{~d}=$ noundb $\& \mathrm{~d}=$ =rient $\& \mathrm{~d}=$ locutio $\& \mathrm{~d}=$ obce $\& \mathrm{~d}=$ priezviska $\& \mathrm{~d}=\mathrm{un} \& \mathrm{~d}=\mathrm{pskc}$ s\&d=psken\# (2020-04-29). 